\title{
Creative Economy Development with Technosociopreneur: Case Study: Halal Travel
}

\author{
Amaliyah \\ Economics and Business Department \\ University of Trilogi \\ Jakarta, Indonesia \\ amaliyah@trilogi.ac.id
}

\begin{abstract}
The purpose of this study is to formulate a development strategy to become a technosociopreneur for the Halal Travel Agency in order to increase tourism rates in Indonesia. The research was done using qualitative method with secondary data obtained from literature studies. The data is then analysed using qualitative descriptive techniques through three stages of analysis, namely data reduction, data presentation, and conclusion drawing. The results of the study show that in order to become a technosociopreneur, Halal Travel Agency must develop expertise and application in technology and improve its social orientation based on the role of the human resources, as well as integrate all parties involved in forming a halal tourism system. The technology that must be mastered and applied primarily is technology to help customers to access information easier, make choices on tourist destinations and packages, and make reservations. The social orientation that must be improved is mainly in terms of efforts to promote domestic halal tourist destinations which subsequently increases the socio-economic impact of the wider community. In addition, through field data collection and testing of the determinants of technosociopreneur in influencing the socio-economic conditions of the Indonesian people it is known that partially the technology, HR and tourism promotion variables significantly influence the socioeconomic community, and it appears that tourism promotion variables have a dominant influence on social economy compared to other independent variables.
\end{abstract}

Keywords- Technosociopreneur, Creative Economy, Halal Travel, Technology, HR and Tourism Promotion

\section{INTRODUCTION}

Sustainable economic development is a process that must be passed in order to achieve the objectives of Indonesia's national development, which in accordance with the mandate of the 1945 Constitution, namely to create public welfare, protect all of Indonesia's bloodline, and help implement world peace and order. National economic development is a long-term development carried out by involving all of the drivers of the nation's economy. One of the drivers that is able to make a significant contribution and is expected to continue to increase is the creative economy sector (Kominfo.go.id, 2015).

Creative economy is interpreted as an economy driven by creativity, therefore the creative economy sector is a business field that utilises creativity to produce development ideas and subsequently generate added value. The creative economy is not just a business that has been determined by sectors, but rather a business concept based on creativity and innovation (Latuconsina, 2014). The contribution of the creative economy sector to Indonesia's Gross Domestic Product (GDP) is very large and continues to increase, amounting to Rp922 trillion in 2016, then in 2017 it reached Rp. 13,587.2 trillion, even in 2018 strengthened again to $\mathrm{Rp}$. 14,837. This condition shows that the creative economy does have the potential to make a major contribution in efforts to achieve national development goals (Putera, 2018).

According to Toffler (1970), creative economy is the fourth economic wave after agriculture, industry, and information, which comes with increasing awareness that physical resources have limitations, hence the creation of ideas needs to be supported by creativity in order to create added value. The basic principle of creative economy in regards to empowering creativity is increasingly important to be implemented with the start of the 4.0 industrial revolution which presents three major challenges for all business people, namely economic challenges, social challenges, and technical challenges (Yahya, 2018). These challenges indirectly encourage the development of compatible strategies for business people to have superior competitiveness through technical innovation in accordance with economic and social demands. In other words, economic actors are required to become technosociopreneur figures in order to face the 4.0 industrial revolution.

Technosociopreneur can be interpreted simply as an individual or business entity that uses technology to run its business, which is not only economically oriented but also aims to provide social services (Depositario, Aquino, \& Feliciano, 2011; Tan, William, \& Tan, 2005). The use of technology and the provision of social services refer to the important role of human resources that are part of the technosociopreneurship. This is in accordance with the basic concept of creative economics which emphasises humans' position as producers of creative ideas or ideas that are needed for development (Latuconsina, 2014).

The object of this research is Halal Travel Agency, which is a halal business travel agency that provides services to consumers who want to travel to various destinations, whether it is in the context of worship, religious tourism, or other trips (Gerintya, 2018). To 
welcome the industrial revolution 4.0, Halal Travel Agency is also required to develop its business into technosociopreneurship. Moreover, Indonesia as one of the countries with the largest Muslim population in the world has many unexplored halal tourist destinations. The development of Halal Travel Agency into technosociopreneurship is expected to encourage the exploration and creation of economic and social values that provide positive impact on the wider community.

Based on the overall explanation above, the formulation of this research's problem is "how the development strategy can be applied by Halal Travel to become a technosociopreneur in order to increase tourism in Indonesia?". In regards to this formula, this research was carried out with the aim to formulate a development strategy to be applied by Halal Travel to become a technosociopreneur in order to increase tourism in Indonesia.

\section{METHOD}

This study uses a combination of qualitative and quantitative approaches, by applying the Sequential Explanatory method. So the data source used also involves secondary data and primary data. The secondary data referred to are journals, research reports, books, modules, or official documents that contain information relevant to the topics studied in this study, while primary data are the results of interviews, observations and the results of questionnaires (Kirk \& Miller, 1986; Sugiyono, 2013).

The qualitative literature review process produces three independent variables and one dependent variable which will be operationalized into a measuring instrument or questionnaire. The first independent variable is technology which is the benefit expected by information system users in carrying out their duties and is measured by the intensity of utilization, the frequency of utilization and the number of applications or software used (Thompson, Christopher, \& Howell, 1991), the second is Human Resources which is human capital in the organization and is measured by quality, roles \& responsibilities, understanding of business regulations, abilities / skills and training (Nurlillah, 2014). Third is tourism promotion which is an activity to notify products or services that would be offered to prospective tourists who are connected with tourist objects and attractions and measured by the contents of messages, forms, responses about attractions and facilities \& infrastructure (Kotler, 2008)

After the variable is operationalized into a measuring instrument (questionnaire) then the questionnaire will then be distributed to respondents. Determination of the respondents in this study using the probability sampling method with simple random sampling techniques provided to the people in Indonesia, especially those involved in halal tourism, including halal travel business people, halal travel consumers, employees, partnerships and sponsors. Because the total population in this study is unknown, the determination of sample size uses the Maximum Likelihood (ML) technique in which a minimum sample of 100 respondents is needed, therefore in this study 100 respondents will be distributed (Ghozali, 2012)

Referring to the variable used is hypothesized that technology, human resources and tourism promos will have a simultaneous and partial effect on the socio-economic community.

\section{RESULTS AND DISCUSSION}

\section{A. Overview of Halal Travel Agency}

Halal Travel Agency is a halal business travel agency that provides services to consumers who want to travel to various destinations, whether it is in the context of worship, religious tourism, or other trips. Halal in this case does not refer to tourism or tourist destinations specifically, but rather to Muslim users who want to fulfil their needs in accordance with the provisions stipulated in Islam, for example regarding halal food or the comfort of resting places which provide worship facilities (Gerintya, 2018).

\section{B. Halal Tourism Potential in Indonesia}

Halal Travel Agency has become one of the business sectors that has experienced rapid development on an on going basis, because it is based on the increasing number of Muslims from years. In accordance with the increase of Muslim demographics, Muslim tourists also have the potential to continually increase in number. Moreover, the data cited by tirto.id from State of The Global Islamic Economy Report 2016/17 stated that Muslim tourists in 2021 are predicted to spend US \$ 243 billion on tourism needs. This value was even predicted to be able to exceed the budget released for medical needs, which was only 213 billion US dollars (Gerintya, 2018).

The future potential of the Halal Travel Agency business is increasing given Indonesia's leading position as the second largest Muslim tourist destination in 2018. Previously, data released by the Global Muslim Travel Index showed that Indonesia became the world's sixth ranked Muslim tourist destination in 2015 with a score of 67.5. Indonesia's ranking was then climbed to number four in 2016 with a score of 70.6 , then rose again to number three in 2017 with a score of 72.6, and finally increased to second place in 2018 with a score of 72.8 (Gerintya, 2018).

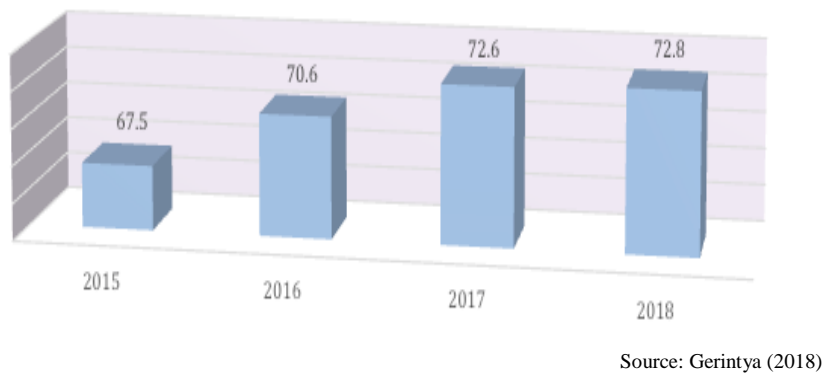

Fig. 1. Indonesia's rank as a Muslim Travel Destination

Refer to the positive trend as Indonesia was ranked second in the world for Muslim tourism destinations in 2018, the competitive climate of halal travel business in the following years will likely increase (Jaelani, 2017). On one hand, it certainly provides a positive value for the development of the national economy, but on the other hand, business entities that are engaged in this field must be able to strengthen and develop their business, therefore they can 
compete with other competitors while still be able to meet the increasing demands of the community.

\section{The Development Strategy for Halal Travel to become a Technosociopreneur}

Indonesia is a country that is rich in natural resources, both underground and on land surface. One of the forms of natural wealth is in the form of natural beauty and various Indonesian cultures that are famous around the world to become the target of foreign tourists. In the past, the foreign tourists only knew Bali as a tourist destination of Indonesia, then after the government made the Wonderful Indonesia tourism campaign, foreign tourists also began to recognise a variety of other tourist destinations are also interesting (www.cnnindonesia.com, 2017).

The target of increasing tourism through Wonderful Indonesia program is continuously developed by targeting GMTI's 2019 first rank on the category of world's largest Muslim tourist destination country. This is based on the positive trend of Indonesia's rank which always increased every year and has been ranked second in 2018 (Primasiwi, 2018). In addition, there are other supporting factors that enable Indonesia to achieve these targets, such as the demographics of the Indonesian population, which are predominantly Muslim, thus implies easy access to Muslim places of worship and halal food. In addition, the dominance of Islam in Indonesia also produces a variety of Islamic cultures that can be enjoyed by Muslim tourists. Hence, in addition to the beautiful and natural scenery of Indonesia, Muslim tourists can also do various other things recommended in Islam such as studying the art of riding, archery, and martial arts.

Halal tourism business is a business that is predicted to grow over time. This is mainly driven by the increasing number of Muslims who want a tourist trip that facilitate various needs of worship in Islam. In addition, the Global Muslim Travel Index (GMTI) mentioned several other driving factors as follows (GMTI, 2018): (i) the growing number of Muslims in middle income groups in countries with large Muslim populations, such the Arab region, Indonesia and Malaysia, (ii) percentage of Muslims at dominant young age, (iii) easier access to information in regards to halal travel, (iv) increasing tourism and travel facilities to accommodate tourism needs for Muslims, (v) religious events, such as the month of Ramadhan, which are the main times of the journey of worship (umrah, hajj), (vi) increasing number of halal travel agents.

Technosociopreneur can be defined as an individual or business organisation that runs its business by emphasising the utility of technological aspects (technopreneur) while still considering the provision of social services (sociopreneur). In this case, the basic concept of Halal Travel Agency itself actually has a strong social orientation, namely providing services to meet the needs of Muslims for halal tourism, hence it can be said that Halal Travel Agency has sociopreneur characteristics. However, the social orientation of Halal Travel Agency still needs to be developed further in order to expand its social impact, therefore the impact is not only gained by the Muslims, but also by other people who are involved in halal tourism. This can be done by increasing the preference of domestic tourist

Identify applicable funding agency here. If none, delete this text box. destinations, in which various Halal Travel Agencies need to work together to promote various halal tourism destinations in Indonesia. In addition to being one of the characteristics in the creative economic era, this cooperation aspect needs to be adapted by every Halal Travel Agency, as it is also an important step that can encourage the development of the Halal Travel Agency business to be more social-oriented. Determining promotion priorities on domestic halal tourism objects will bring socio-economic impacts, both to Halal Travel Agency and to the community as well as various businesses involved in the implementation of domestic halal tourism. In other words, the development of Halal Travel Agency into a sociopreneur can be seen from the impact of increasing domestic halal tourism exploration.

According to the data presented by GMTI (2018), it can be seen that Malaysia is the first country that has been ranked as the largest Muslim tourist destination in the world for eight years. Indonesia, which in 2018 finally managed to occupy the second place, was also categorised as a Muslim tourist market.

The Halal Travel Agency process towards technosociopreneur is actually exist, namely the use of communication and information technology, such as the internet, web sites, and social media as marketing instruments. Some examples of Halal Travel Agency websites from Indonesia include: www.cheria-travel.com; www.halalkonsorsium.com; $\quad$ www.esqtours.com; www.athin.org (Indonesian halal travel association), and others. In general, the entire Halal Travel Agency offers halal concept travel facilities, both for religious purposes, such as Umrah or Hajj, or for tourist destinations to various domestic and foreign tourist destinations. In this case, the use of information technology has indeed made it easier for customers to access information provided by Halal Travel Agency for further ordering online, where it is one of the characteristics of technopreneurs.

Overall, the strategy of developing Halal Travel Agency into technosociopreneur can be formulated in the following steps: (i) to have the needed technology to assist customers to access information, make choices on tourist destinations packages, as well as make bookings, (ii) to employ human resources who understand and implement Islamic law, able to operate various technologies used in business processes, and have high creativity to produce further development ideas, (iii) to prioritise the promotion of domestic tourist destinations in order to increase the socio-economic impact of the wider community, (iv) to integrate the roles and functions of all parties involved halal tourism system establishment.

Based on the explanation above, we can draw the red line that determines that Halal Travel Agents can become technosociopreneur, so that being able to increase tourism in Indonesia and improve the community's economy is:

\section{1) Technology}

Thompson et al. Define the use of technology as a benefit expected by users of information systems in carrying out their duties where measurement is based on intensity of use, frequency of use and number of applications or software used. Romney states that the use of technology in organizations will affect the business activities / processes 
contained in the organization. The influence of technology use in organizations can be seen from the impact of using technology on the value chain (Romney, 2006).

\section{2) Human Resources}

Human capital is a person's knowledge, skills and abilities that can be used to produce professional services and economic value. Human resources are a source of innovation and ideas. Employees with high human capital are more likely to provide services that are consistent and highly competent, so that the quality of human resources is determined by the mental attitude of humans (Yanto, 2013). Nurlillah stated that Human Resources can be measured by quality, role \& responsibility, understanding business rules, abilities / skills and training (Nurlillah, 2014).

\section{3) Tourism Promotion}

Tourism is always related to the instinctive needs of humans to know, search, learn and enjoy something not found in their homes (Nyoman, 2002). Thus, it can be interpreted that tourism promotion is an activity to notify products or services offered to prospective tourists associated with tourist objects and attractions. Tourism promotion is measured by indicators of message content, forms, responses about attractions and facilities \& infrastructure (Kotler, 2008).

After knowing the determinants that make Halal Travel Agents as technosociopreneur, then testing the quality of data will then be carried out which includes tests of validity \& reliability, normality, and then multiple linear regression analysis, the complete results are as follows:

TABLE I. VARIABLE VALIDITY \& RELIABILITY TEST RESULTS

\begin{tabular}{|c|c|c|c|c|}
\hline Variabel & Indicator & Validity & Signifance & Reliability \\
\hline \multirow{3}{*}{ Technology (X1) } & $\mathrm{X} 11$ & 0,662 & 0,000 & \multirow{3}{*}{0,684} \\
\hline & $\mathrm{X} 12$ & 0,845 & 0,000 & \\
\hline & $\mathrm{X} 13$ & 0,835 & 0,000 & \\
\hline \multirow{5}{*}{$\begin{array}{l}\text { Human Resource } \\
\text { (X2) }\end{array}$} & $\mathrm{X} 21$ & 0,742 & 0,000 & \multirow{5}{*}{0,841} \\
\hline & $\mathrm{X} 22$ & 0,776 & 0,000 & \\
\hline & $\mathrm{X} 23$ & 0,812 & 0,000 & \\
\hline & $\mathrm{X} 24$ & 0,840 & 0,000 & \\
\hline & $\mathrm{X} 25$ & 0,740 & 0,000 & \\
\hline \multirow{4}{*}{$\begin{array}{l}\text { Tourism } \\
\text { Promotion (X3) }\end{array}$} & $\mathrm{X} 31$ & 0,854 & 0,000 & \multirow{4}{*}{0,873} \\
\hline & X32 & 0,891 & 0,000 & \\
\hline & X33 & 0,828 & 0,000 & \\
\hline & X34 & 0,829 & 0,000 & \\
\hline \multirow{2}{*}{$\begin{array}{l}\text { Socio-economic } \\
\text { (Y) }\end{array}$} & Y1 & 0,906 & 0,000 & \multirow{2}{*}{0,797} \\
\hline & $\mathrm{Y} 2$ & 0,918 & 0,000 & \\
\hline
\end{tabular}

1) After the text edit has been completed, the paper is ready Travel and its determinants to become technosociopreneur in order to increase tourism in Indonesia. To be able to become a technosociopreneur, Halal Travel Agencies must develop mastery and application of technology and improve their social orientation based on the role of human resources, and

TABLE II. REGRESSION TEST RESULTS EFFECT OF TECHNOLOGY, HUMAN RESOURCES AND TOURISM PROMOTION ON SOCIOECONOMIC

\begin{tabular}{|c|c|c|c|c|}
\hline Variabel & $\begin{array}{c}\text { Regresion } \\
\text { Coefficient }\end{array}$ & $\mathbf{T}_{\text {count }}$ & $\begin{array}{c}\text { Signifance } \\
\text { Value }\end{array}$ & Descriptoon \\
\hline constanta & 1,098 & 0,840 & 0,403 & n.a \\
\hline $\begin{array}{c}\text { Technology (X1) } \\
\text { Human Resource } \\
(\mathrm{X} 2)\end{array}$ & 0,153 & 2,109 & 0,038 & Significant \\
\hline $\begin{array}{c}\text { Tourism } \\
\text { Promotion (X3) }\end{array}$ & 0,186 & 3,447 & 0,001 & Significant \\
\hline \multicolumn{5}{|c|}{$\mathrm{F}_{\text {count }}=8,746(0,000)$} \\
\hline \multicolumn{5}{|c|}{$\mathrm{R}$ square $=0,215(21,5 \%)$} \\
\hline
\end{tabular}

Referring to the test results in table II above can be interpreted as follows:

\section{a) Simultaneous Influence}

Table II shows that the calculated F value is 8.746 with a significance of 0,000 so that it can be concluded that all variables have a significant effect simultaneously on the dependent variable. However, if seen from the Rsquare value of $0.215(21.5 \%)$, it shows that there are still many other variables that can influence the dependent variable other than the variables found in this study.

\section{b) Partial Influence}

1. Effect of Technology on socio-economic conditions Based on the test results presented in table II, it is known that the tcount of technological variables is 2.109 with a significance of 0.038 and smaller than the critical value required 0.05 . So, it is stated that partially the technology variable has a significant influence on the socio-economic community.

2. The influence of HR on socio-economic conditions Based on the test results presented in table II, it is known that the HR variable $t$ count is 2.329 with a significance of 0.022 and smaller than the critical value required, which is 0.05 . So, it is stated that partially the $\mathrm{HR}$ variable has a significant influence on the socioeconomic community.

3. Effect of tourism promotion on socio-economic conditions

Based on the test results presented in table II, it is known that the value of the variable tourism promotion variable is 3.447 with a significance of 0.022 and smaller than the critical value required at 0.05 . So it was stated that partially tourism promotion variables had a significant effect on the socio-economic community.

\section{CONCLUSION}


integrate all parties involved in forming a halal tourism system to optimally promote halal tourism optimally. The technology that must be mastered and applied is primarily technology that can make it easier for customers to access information, create destinations and tour packages, and book a place. The social orientation must be improved especially in the effort to promote domestic halal tourist destinations to increase the socioeconomic impact of the wider community

2) The influence of technosociopreneur determinants on socio-economics. Partially the technology, HR, and tourism promotion variables have a significant influence on the socio-economic community, and it appears that tourism promotion variables have a dominant influence on socio-economic compared to other independent variables.

\section{SUGGESTION}

Findings that have been presented previously, recommendations or suggestions that can be given are as follows:

1) Based on the literature formulation which is then followed up by looking at the direct conditions in the field, it is known that the efforts that can be made by Halal Travel and is a determinant of becoming a technosociopreneur in increasing tourism in Indonesia are technology, human resource promotion and tourism which when tested simultaneously only has a $21.5 \%$ influence on the socio-economic conditions of the Indonesian people. Therefore, further research is expected to conduct research by adding other variables that have a potential influence on socio-economic communities,

2) Based on the results of the partial test, it is known that tourism promotion is the main determinant that has a significant influence, while technology has the least influence compared to other variables. For this reason, it is expected that stakeholders and the government can further enhance the capacity and adaptation of community technology by conducting publications, training and publishing policies on this issue, and further promoting the promotion of tourism with more modern media and broad reach through digital bases.

\section{REFERENCES}

[1] Depositario, Aquino, \& Feliciano. (2011). Entrepreneurial Skill Development Needs of Potential Agri-Based TechnopreneursISSAAS, 17(1), 106-120.

[2] Firdausy, C. M. (2017). Strategi Pengembangan Ekonomi Kreatif di Indonesia. Jakarta: Yayasan Pustaka Obor Indonesia.

[3] Gerintya, S. (2018). Peluang Indonesia Menggaet Pasar Wisata Ramah Muslim. Retrieved from https://tirto.id/peluang-indonesiamenggaet-pasar-wisata-ramah-muslim-cMxq
[4] GMTI. (2018). Global Muslim Travel Index.

[5] Irfan, P., \& Apriani. (2017). Analisa Strategi Pengembangan etourism sebagai Promosi Pariwisata di Pulau Lombok. ILKOM Jurnal Ilmiah, 9(3), 325-339.

[6] Jaelani, A. (2017). Halal tourism industry in Indonesia: Potential and prospects. Munich Personal RePEc Archive, 1-19.

[7] Kirk, J., \& Miller, M. L. (1986). Reliability \& Validity in Qualitative Research. Beverly Hills, CA: Sage Publishing.

[8] Kominfo.go.id. (2015). Era Ekonomi Kreatif: Harus menjadi tulang punggung Indonesia. Retrieved from https://kominfo.go.id/content/detail/5419/ekonomi-kreatif-dorongpertumbuhan-ekonomi/0/berita.

[9] Latuconsina, Hu. (2014). Pendidikan Kreatif: Menuju Generasi Kreatif \& Kemajuan Ekonomi. Jakarta: PT Gramedia Pustaka Utama.

[10] Primasiwi, A. (2018). Kembangkan Wisata Halal, Wonderful Indonesia Bidik Peringkat Satu GMTI Master Card Report 2019. Retrieved from https://www.suaramerdeka.com/travel/baca/87621/kembangkanwisata-halal-wonderful-indonesia-bidik-peringkat-satu-gmti-mastercard-report-2019.

[11] Putera, A. D. (2018). Bekraf: Kontribusi Ekonomi Kreatif ke PDB 2018 Lebih dari Rp 1.000 Triliun Artikel ini telah tayang di Kompas.com dengan judul "Bekraf: Kontribusi Ekonomi Kreatif ke PDB 2018 Lebih dari Rp 1.000 Triliun”, https://ekonomi.kompas.com/read/2018/08/01/1709007.

[12] Samparaya, C. F. (2018). Malaysia Gencar Menarik Wisatawan Muslim Indonesia. Retrieved from https://travel.kompas.com/read/2018/11/02/091600327/malaysiagencar-menarik-wisatawan-muslim-indonesia.

[13] Subarkah, A. R. (2018). Potensi dan Prospek Wisata Halal Dalam Meningkatkan Ekonomi Daerah (Studi Kasus: Nusa Tenggara Barat). Jurnal Sospol, 4(2), 49-72.

[14] Sudarsih, \& Endang. (2013). Pendidikan Technopreneurship: Meningkatkan Daya Inovasi Mahasiswa Teknik dalam Berbisnis. Prosiding KNIT RAMP-IPB, 56-63.

[15] Suryana. (2013). Ekonomi Kreatif: Ekonomi Baru: Mengubah Ide dan Menciptakan Peluang. Jakarta: Salemba Empat.

[16] Tan, W. L., William, J., \& Tan, T. M. (2005). Defining the social in social entrepreneurship: Altruism and Entrepreneurship. International Entrepreneurship and Management Journal, (1), 353365.

[17] Thomas, H., Smith, R. R., \& Diez, F. (2013). Human capital and global business strategy. New York: Cambridge University Press.

[18] Toffler, A. (1970). Future Shock. New York: Random House.

[19] Utomo, H. S. (2012). Pemberdayaan Masyarakat Melalui Pendekatan Sociopreneurship. Business Conference.

[20] Wicaksono, E. K., \& Nurnida, I. (2017). Analisis Penerapan Technopreneurship pada Perusahaan Energi Alternatif (Studi Pada CV Wahana Putera Ideas Bandung). E-Proceeding of Management, 4(2), 1831-1837.

[21] Www.cnnindonesia.com. (2017). Promosi Wonderful Indonesia Bikin Pariwisata RI Cemerlang. Retrieved from https://www.cnnindonesia.com/gaya-hidup/20171028164531-307251849/promosi-wonderful-indonesia-bikin-pariwisata-ri-cemerlang.

[22] Yahya, M. (2018). Era INdustri 4.0: Tantangan dan Peluang Perkembangan Pendidikan Kejuruan Indonesia. Makassar.

[23] Zuhal. (2010). Knowledge \& Innovation: Platform Kekuatan Daya Saing. Jakarta: PT Gramedia Pustaka Utama. 